\title{
Remote sensing of the earth by satellites and the principle of territorial sovereignty*.
}

\section{Valnora Leister}

SUMMARY:

I. INTRODUCTION

II. General Characteristics of Remote Sensing activities

1. Remote Sensing Defined

2. Platforms for Remote Sensing

3. Main Applications

a. Peaceful Uses

b. Military Uses

4. Interpretation of Data

5. Achievements in Remote Sensing

III. Remote Sensing and the Princtple of Terrtrorial Soveretgnty

1. The Fredom of Outer Space and the Remote Sensing Activities by Satellites

2. The Concept of Territorial Sovereignty in National and International Law

3. The Extension of the Territorial Sovereignty

4. General Principles of International Law Relating to State Sovereignty

IV. The Concept of espionage in International Law

1. Introduction

2. Espionage in Conditions of Armed Conflict

3. Peacetime Esplonage

4. Espionage Conduced from Outer Space

a. Military

b. Economic

v. CURrent Reguiations of Remote Sensing activities

*. A Term-Paper Presented to the Institute of Alr and Space Law. McGill Oniversity, Montreal. April, 1976. 
1. Bllateral Agreements

2. Current Draft Proposals Before the U.N. Outer Space Committee

vi. ConClUSIONS AND RECOMMENDATION:

1. Conclusions

2. Recommendations

Notes

BibLtography.

\section{Introduction.}

During the past twenty-five years, there has been an increasing realization, at least intellectualy, of the serious threat to the security of the world through wide disparaties in the standards of living in the different regions of the world.

In spite of much that has been attempted bilaterally, regionally and through international agencies, the gap between developing and advanced nations has widened rather than decreased.

For the developing country, the principle economic assets are human and natural resources ${ }^{1}$, but only when such resources are known and exploited. A mineral deposit hidden below a cover of soil is an asset to no one until its existence is discovered.

At the present time, it is largely the few technically advanced nations which possess the means required to benefit from the uses of outer space. As one observer notes:

"The benefits which the developing countries derive from bilateral space arrangements with the advanced states have been extremely modest...

1. Definition of natural resources according to McKelvey classification: Resource: a concentration of naturally occurring solid, liquid or gaseous materials in or on the earth's crust in such form that economic extraction of a commodity is currently or potentially feasible. in U.N. Doc. E/C 7/52 ADD 1.4 March 75. - Comm. on Natural Resources - 4th session - Tokyo. 
The practical benefits flowing from such arrangements to the countries which have only their territory to offer in exchange have by and large been limited to the on-site training of a small number of their nationals.

The examination of space agreements concluded during the past decade by the United States and the Soviet Union with other countries shows that these agreements favor the technologically advanced nations." 2

Those involved in this new technology are fully convinced of its great potential to change the face of the earth, if properly handled and applied.

The United Nations Committee on Natural Resources working on the 'Plan of Action for and Co-ordination of Programmes within the United Nations System in the Field of Natural Resources Development' based its program on the following Assembly's statement:

"All efforts should be made. to take measures for the recovery, exploitations, development, marketing and distribution of natural resources, particularly of developing countries, to serve their national interests, to promote collective self-reliance among them and to strengthen mutually beneficial international economic cooperation with a view to bringing about the accelerated development of developing countries." 3

Today, investigation of earth resources from outer space provides a unique opportunity to view from a distance the

2. I. A. VuAsIC Space Lawyers, New Technology and the Question of Priorities, In Steinhorf, ed., Organizing Space Activities for World Needs, (1971) p. 219.

3. U.N. Doc. E/C 7/47 Add. 317 Jan. 75. Committee on Natural Resources - 4th session - Tokyo. 
composition and content of our planet. Presently, unmanned orbiting satellites are gathering important information about earth resources and relaying this information back to earth stations.

Although remote sensing activities take place in outer space, where state sovereignty does not apply, it is exclusively of direct interest to the development of our planet, as it obtains information concerning the territory of a country to which state sovereignty applies.

Among the important legal questions raised by the use of satellites in remote sensing activities, the following are of special interest:

- Is the launching state permitted to acquire data about other nations without their prior consent?

- Can data acquired about a nation be used by or disseminated to other nations without the consent of that nation?

- What is the present legal status of remote sensing activities?

This study will analyze the different activities performed by remote sensing satellites, considering the principle of territorial sovereignty, as it cannot be denied that as long as the world is divided into sovereign states, the national interest is and will continue to be the most important determinant policy.

It will also attempt to establish the main guidelines that should govern these activities, in order to decrease the gap between poor and rich nations, as international law cannot play its regulatory role by isolating itself from the political realities. 


\section{General characteristics of remote sencing activities.}

1. Remote Sensing Defined.

In its third session, the Working Group of Remote Sensing of the Earth by Satellites (13/03/74) provided that:

"Remote sensing of the earth from space is a methodology to assist in characterizing the nature and conditions of the natural resources, natural features and phenomena, and the environment of the earth by means of observations and measurements from space platforms. Specifically at present, such methods depend upon, the emission and reflection of electromagnetic radiation.

A remote sensing system comprises all those elements required for the purposes described above and consists of a space segment and a ground segment. The former comprises a platform from which the earth can be observed, sensors of whatever variety to make these observations and take measurements, some means of transferring these data to the earth. The latter comprises at least one ground terminal for reception of such data, data processing and data interpretation facility or facilities." 4

2. Platforms for Remote Sensing.

The higher the elevation of the sensing platform the greater is the arca viewed on the surface of the earth.

A satellite platform at nearly $36,000 \mathrm{~km}$ will continuously cover a third of the globe, although in this case the resolution - the smallest area whithin which features can be

4. U.N. Doc. A/AC $105 / 110$, p. 12. 
discriminated with modern instrumentation - will be about $3 \mathrm{~km} \times 3 \mathrm{~km}$.

From an altitude of $900 \mathrm{~km}$, the sensors can view the surface of an area about $185 \mathrm{kh} \mathrm{x} 185 \mathrm{~km}$, and can cover the whole earth surface in 17 days; the resolution area will be $150 \mathrm{~m} \times 150 \mathrm{~m}$.

An aircraft flying at an altitude of $10 \mathrm{~km}$ can cover an area of 5,000 square $\mathrm{km}$ in a three hour sortie. The earth's surface being $5 \times 10$ billion square $\mathrm{km}$, it would require 100,000 sorties or thirty-five years for one aircraft to cover the globe.

The there are some cases in which remote sensing from aircraft or from spacecraft may be the only means of acquiring certain types of data. In most cases a combined system of spacecraft and aircraft remote sensing will be more economical.

3. Main Applications.

a. Peaceful Uses.

i. Forestry and Agriculture.

An essential requirement for any agricultural management system is the availability of timely information on agricultural conditions.

Repetitive aerial surveys during the vegetative growth and harvest times of a crop can provide reliable inventories of the size of the harvest. Remote sensing from orbiting satellites extend such predictive techniques to very large areas with many crops such as rice, wheat, maize, etc.

With the use of scanners and imaging systems it is possible to provide pictures of agricultural features in different wave-lengths. Different plants have different reflect- 
ivities in different wave-lengths. This technique is kown as multispectral imagery.

Use of multispectral imagery can help in the identification of crops and timber species, in the analysis of crop vigour, in the early detection of crop diseases and other forms of crop stress, for example, stress due to deficient water supply. The evaluation of the large scale effects of different kinds of fertilization and irrigation practices on agricultural land can be carried out more satisfactorily through remote sensing techniques than through isolated ground measurements at a few selectedspots. The utility of repetitive observations of large agricultural areas over a short period of the order of one month cannot be over-emphasized. Remote sensing is the only technique capable of achieving this with any degree of reliability. ${ }^{5}$

\section{ii. Oceanography and Marine Resources. ${ }^{6}$}

Oceanography is concerned with the physical, chemical, and biological character of the ocean at all depths, its behavior as a dynamic global system, and its interactions with the atmosphere, the coasts, and the inhabitants of the coasts.

The science of oceanography has been developed over the years by the hard work of a comparatively few people operating largely from ships.

Satellites can sample, at most, the top few hundred feet (or about one percent) of the ocean's depth, which is just the portion that is most important to man in his fishing, shipping, and coastal activities. It also includes the photosynthesis zone that provides the nutritional basis for the entire biological resource of the sea; the air-sea interface across which the major energy exchanges occur.

5. The application of Space Technology to Development U.N., 1973, p. 42.

6. Ibia. p. $43-47$. 
The state of the sea produces differences in the sea colour when viewed vertically. Remote sensing techniques for these features installed in spacecraft can provide information on the state of the sea, which can be used for appropriate rerouting of ships along routes which offer less resistance to the ship's motion.

\section{iii. Hydrology and Water Resources. ${ }^{7}$}

Hydrology is concerned with the entire water cycle.

Applied hydrology concerns all practical uses of terrestrial waters, notably for industrial, agricultural and domestic purposes.

Present engineering hydrology know-how could mitigate man's water problems almost anywhere, but at prohibitive costs.

There are huge gaps in hydrology theory and in observational data. Hydrologists have only limited knowledge of the discharge of the major rivers of the world. The number of lakes (greater than 200 square kilometers surface area), the amounts of annual snow, world precipitation, evaporation, soil moisture, and other hydrologic components are not known with confidence.

The broad goal of hydrology is to attain sufficient knowledge of the environment for understanding, prediction and management at appropriate time and space scales.

Earth-oriented satellites can contribute technically to the achievement of these goals by providing hydrologic data of various types that are too costly to obtain repetitively, on a global scale, and with adequate resolution, by current observational techniques.

7. Ibid. 


\section{iv. Geology and Mineral Resources. ${ }^{8}$}

It is well known that the primary, non-human inputs into a nation's economy are the mineral resources, and that the economic growth of a nation depends upon the discovery and effective use of those resources.

One of the geologist's chief information tools is the geological map which shows the distribution of rocks exposed at the earth's surface. Large scale geological maps were the laborious product of years of surface exploration. Now geologists can have the big synoptic view offered by remote sensing. These systematic space pictures will offer geologists a broad, integrated panorama from which they can select observables of interest for close up looks by aircraft or ground parties. The advantage offered by observations from space is specific areas of interest.

v Geography and Cartography. ${ }^{9}$

The compilation of small-scale maps is a slow laborious process, even when aerial photography is employed. At least a satisfactory photo-mosaic of a country the size of India, half a million such photographs would be required to map From a satellite positioned in outer space, such a panorama of India would require no more than 200 pictures, which could be assembled in a few weeks.

Placed in an appropriate sun-synchronous orbit, a satellite is capable of producing pictures of the earth under lighting conditions which change very slowly. Satellite pictures are geometrically superior to aircraft photographs of largeareas because of the near vertical view. The distortions caused by oblique camera angles are eliminated. New maps made by satellite effectively supplement existing specialized maps

\footnotetext{
8. Ibid.

9. Ibia. p. 47.
} 
and together will be of great value to all of the geographical disciplines.

Demographers will have new, updated imagery to use in assessing changing patterns of population and migration. Regional planners, transportation planners and cultural geographers will also strengthen their analysis with this new information.

vi. Meteorology. ${ }^{10}$

The use of satellites as platforms to observe the earth's weather is one of the first and best known earth-oriented application of space technology.

Recent advances in the ability to model the behavior of the large scale atmospheric motin, using numerical methods, together with the availability of much larger, higher speed electronic computers, make it possible to produce operationally useful forecasts of large scale weather patterns up to a week or more in advance.

b. Military Uses.

In the field of space activities it is extremely difficult to make and maintain a rigid distinction between civilian and military programs since many satellites have dual uses, at least potentially.

The United States made a policy decision to place prime emphasis in its space program on a civilian agency, NASA; yet what is developed for NASA programs is often also: of direct or applied use in military programs. NASA's astronauts, like the Soviet Union's cosmonauts, in general have been

10. see Useful Applications of Earth-Oriented Satellites Division of Engineering-National Research Council for the National Aeronautics and Space Administration - Published by the National Academy of Sciences - 1969 page 16. 
military officers. The are also joint NASA - Defense Department Programs. According to Professor Vlasic:

"Despite a broad variety of scientific programs now carried out by means of space technology, one must not overlook the fact that the main driving force behind many contemporary advances in space science and technology has been and continues to be the quest for military supremacy, rather than the attainment of scientific, technical, industrial or prestige goals..." 11

Remote sensing had evolved primarily from military reconnaissance systems. Typical examples are the infrared scanners used for night observations and camouflage detection, and side looking airborne radar for height resolution, all weather, day and night imaging. Reconnaissance spacecraft reached such sophistication that they are being used for onsite inspection in arms control agreement. ${ }^{12}$ Because of secrecy, their total number is not know. In 1975, as justifieation for additional money for-surveillance of space, the Pentagon cited "the growing Soviet utilization of space for strategic and tactical purposes." Studies are being made to determine whether the space detection system can serve as a warning against satellite attacks. Satellite surveillance of space is also being considered. ${ }^{13}$

\section{Interpretation of Data.}

The data collected through remote sensors located on spacecraft platforms will be mostly in the form of images on films.

11. In Falk \& Black, eds. The Future of the International Legal Order, v. II, Ch. 4: I.A. VLASIC, The Relevance of International Law to Emerging Trends in the Law of Outer Space (1970) page 281.

12. See LANDSAT photos showing Soviet and Chinese launch facllities In Aviation Weele \& Space Technology, Dec. 11, 1975 and Feb. 9, 1976 - coples attached.

13. see The Defense Monitor - Center for Defense Information Washington D.C. v. IV, n. 5, July 1975, pp. 2, 4. 
Having developed the necessary skills for interpreting the images, it is also necessary to check and validate the conclusions through independent and simultaneous information obtained through ground-based instruments. The whole process is known as the determination of "ground truth".

Without adequate experience, even the shapes of objects seen in vertical view are sometimes suprisingly difficult to interpret.

Despite a reduction in volume of data per unit area, satellites will generate vast volumes of data through their repetitive flights. Such a profusion of data will create new and complex problems of data handling, analysis and use, as, for instance, the sorting of useful data, monitoring change, systematic recognition of objects and phenomena, and automated procedures of interpreting their meaning.

This, data handling and processing can be expected to remain for several decades a major obstacle to the full utilization of remote sensing.

\section{Achievements in Remote Sensing.}

All remote sensing programs carried out so far or being carried out at the present time, have been experimental in nature. These programs have been performed only by the two big space powers, the U.S.A. and U.S.R.R., both from manned and unmanned space platforms.

The first earth observation satellite, the TIROS-I was launched by NASA on April 1, 1960. Its impact in the field of meteorology was overwhelming.

It is anticipated that the first major operational remote sensing program will be the us Earth Observatory Satellite (EOS), program planned for the 1980's. ${ }^{14}$

14. 1975 - NASA authorization, Hearings before the Subcommittee on Space Science and Applications - the Committee on Sciences and Astronauts, U.S. House of Representatives - 93rd Cong. 2nd Sess., on HR 12689, HR3998, Feb. 26, 27, 28, March, 5, 6, 7, 14, 19, part 3. 
The two most important U.S. remote sensing experiments have been the ERP and ERTS/LANDSAT programs The former program has been completed whereas the latter is still in operation. The ERP carried by Skylab acquired data in the form of 40,000 pictures and 70,300 meters of magnetic tape on 440 test sites in the U.S. and 39 other countries. ${ }^{15}$

LANDSAT 1 and 2 circle the globe 14 times a day, scanning a swarth of earth's surface 185 kilometers wide in green, red and infrared spectral bands.

The LANDSAT program is managed for NASA's Office of Applications by the Goddard Space Flight Center at Greenbelt, Maryland. LANDSAT signals are received by three ground stations in the UsA: Goddard, Fairbanks (Alaska) and Goldstone (Califórnia) Only Goddard is equipped to turn the electronic signals into pictures. Goddard sends all these pictures on computer tapes to the Dept. of Interior's Earth Resouces Observation System. Eros. Data Centeer at Sioux Falls (South Dakota) for distribution.

In accordance with bilateral agreements concluded with the United States, Canada and Brazil have their own LANDSAT ground stations. Canada's is at Prince Albert and Brazil's is at Cuiaba. Italy, also, has a ground station at Fucinos. Iran and Zaire will build their own ground stations. ${ }^{16}$

Examples of important achievements in remote sensing: ${ }^{17}$

- Brazilian investigators have found that the courses of a number of tributaries of the Amazon

15. NASA New Realease n. 74330, page 8, 1975.

16. GaLlowaY, Introduction Report, in Proceedings on the Law of Outer Space, XVIth Coll., 1973, page 91.

17. in U.S. Doc. A/AC. $105 / 125$ - 13 March 1974 - Committee on the Peaceful Uses of Outer Space, p. 8. 
River are very different from the ones shown in direction being off as much as 90 degrees. Islands of 200 square kilometers exist which were not shown on previous maps.

- Canada has initiated a programme using ERTS satellite data to monittor the distribution and movements of sea ice and icebergs to aid shipping in northern waters.

- Egyptian scientists have identified from space imagery a number of geological faults intersecting Lake Nasser which has not been identified previously by extensive aerial and ground surveying. This information could be significant in controlling seepage from the lake.

- Japanese scientists have studied the water pollution in the Seto Inland Sea area caused by the concentration of industries in this area. As a result of the study so far carried out, it has been already shown that remote sensing data acquired from space are very useful for the monitoring of water pollution. Such monitoring will facilitate the taking of remedies and the new planning of land use.

- The Government of Pakistan is utilizing space imagery taken before, during and after recent floods of the Indus River to assess the damage and assist in recovery efforts.

\section{Remote sensing and the principle of territorial sovereignty}

1. The Freedom of Outer Space and the Remote Sensing Activities by Satellites.

Although remote sensing is an activity carried out in the outer space, where there is no sovereignty, the data is collec- 
ted for potential use on the earth, where state sovereignty prevails in territory and airspace. The question arises, then, whether it is appropriate to have the Outer Space Treaty applied to an activity which is so overwhelmingly earth oriented.

The Outer Space Treaty ${ }^{18}$ provides that:

Art. I:

The exploration and use of outer space, including the moon and other celestial bodies, shall be carried out for the benefit and in the interests of all countries, irrespective of their degree of economic or scientific development, and shall be the province of all mankind.

Outer space, including the moon and other celestial bodies, shall be free for exploration and use by all states without discrimination of any kind, on a basis of equality and in accordance with international law, and there shall be free access to all areas of celestial bodies.

There shall be freedom of scientific investigation in outer space, including the moon and other celestial bodies, and states shall facilitate and encourage international cooperation in such investigation.

Art. II: Outer space, including the moon and other celestial bodies, is not subject to national appropriation by claim of sovereignty, by means of use or occupation, or by any other means.

18. U.N. Doc. A/RES/222 (XXI) - 25 Jan. 1967. Treaty on Principles governing the activities of states in the exploration and use of outer space, including the moon and other celestial bodies. 
The treaty also establishes certain conditions for the exercise of this freedom such as:

i. the obligation to use outer space in accordance with international law and the U.N Charter (art. III)

ii. the obligation to conduct activities with due regard for the corresponding interest of all other contracting states (art. Ix)

iii. a duty to inform the U.N Secretary General anad the public, to the greatest extent feasible and practicable, of the nature, conduct, locations and results of national space activities.

From the analysis of these conditions, it may be concluded that the only restrictions which might bear upon the observation from outer space of the territory of one nation by another are those contained in the obligation to act in accordance with international law and to respect the "corresponding' interests of other states, as well as the duty to inform the United Nations Secretary General and the public, to the greatest extent feasible and practicable, of the nature, conduct, locations and results of national space activities.

The only article which might be invoked to give some limited support to the objection to the use of satellites surveying resources of another state is art. III providing that activities in the exploration and use of outer space must be carried out in such a way as to promote international cooperation and understanding. Therefore, if the activities are objected to by a number of states and create international friction instead of understanding, they may be regarded as violating the spirit if not the letter of the Treaty.

Dissemination of data seems mandatory within the general conditions set forth in the Treaty (art. XI) . 
According to Professor Gorove ${ }^{19}$ :

"The reference in art. 1 of the Outer Space Treaty that the exploration and use of outer space shall be carried out for the benefit and in the interests of all countries may or may not be interpreted to apply to the use of earth resources survey satellites. From the wording of this provision, it is not entirely clear whether 'exploration' has to precede 'use' or whether 'use' must be accompanied by exploration. Consequently the use of outer space by such satellites without exploration of outer space and solely for exploration of earth resources may preclude applicability of the quoted provision. For analogous reasons one could also question the applicability of art. III and other articles of the Treaty which similarly refer to 'exploration and use' of outer space. What lends suport to such interpretation is the fact that the drafters of the Treaty could easily have used the phrase exploration 'or' use instead of the expression exploration 'and' use but they have not."

If the principle of freedom is established for remote sensing activities, then, only the states that are developed have the means of placing in orbit a remote sensing satellite and only a minority of states is able to explore the data received. To be in accordance with international law, remote sensing activities must respect the principle of territorial sovereignty.

2. The Concept of Territorial Sovereignty in National and International Law.

In the Midle Ages, the idea of state and kingship prevalent in Europe tended to place the ruler in the position

19. S. Gorove - Earth Resources Survey Satellites and the Outer Space Treaty (Journal of Space Law - v. 1.1 p. 81). 
of a private owner since feudal law, as the applicable 'public law' ${ }_{2}$ conferred ultimate tible on the ruler. The growth of absolutism in the xvI and xvi Centuries confirmed the trend. A treaty ceding territory had the appearance of a sale of land by a private owner and sales of territory did in fact occur.

In the XviII and XIx centuries the significance of the theory of sovereignty was recognized as an abstraction and thus the ruler was a bearer and agent of a legal capacity which belonged to the state. In Europe and the Americas, the principle of self-determination has become important.

During the XIX century, the concept of sovereignty was enriched through the principle of non-intervention, of noninterference in the internal affairs of other countries.

According to De Visscher ${ }^{20}$, the theory of relative sovereignty acknowledges the fact that the individual states are included in a pattern of relationships which necessarily imposes certain limitations upon their will to be autonomus. This theory provides the essential prerequisites for the coexistence of states within the international community.

The adoption of the United Nations Charter is considered the most far-reaching development in the history of the relation between international law and sovereignty. It is a constitutional instrument which obliges states to abide by future decisions of the organization, even without the consent of the particular state, in areas that were formerly the subject of state sovereignty.

While it reaffirms sovereignty, the Charter does not define it in the traditional terms, but in those of 'sovereign equality' (art. 1, par. 1).

20. C. DE VISScher - Theorie et realité en Droit International Public Par1s, 1953, p. 30 . 
The sovereignty of states implies that they may not be subjected to one another, and this subjection is also precluded by their equality.

The Charter tends, in a sense, to restrict sovereignty. The restrictions are, basically, a further stage in the process of adjusting sovereignty to the needs of an interdependent world.

The obligations of states to settle their disputes by peaceful means is, basically, merely the affirmative side of the prohibition of the threat or use of force in international relations and therefore involves the same degree and kind of limitation of sovereignty.

The subordination of national sovereignty to international law is demonstrated when, through operation of the U.N System, actions are taken which are binding upon a sovereign state without its consent. This can come about both as to non-members and as to members. ${ }^{21}$

The sovereignty in its internal aspect is dealt within the U.N. Charter under the title of the domestic jurisdiction of states, and the progressive doctrine teaches that its erosion by international law is necessary to the establishment of a sound international legal order.

In summary, the principal characteristics of sovereignty in national and international law are:

a) jurisdiction over a territory and the permanent population living there

b) duty of non-intervention in the area of exclusive jurisdiction of other states

21. U.N. Charter Art. 2(6) states: "The organization shall ensure that states which not members of the United Nations act in accordance with these principles so far as may be necessary for the maintenance of international peace and security." 
c) dependence of obligations arising from customary law and treaties on the consent of the obligor. ${ }^{22}$

\section{The Extension of the Territorial Sovereignty.}

The territorial sovereignty extends principally over land territory, the territorial sea appartenant to the land, the seabed and subsoil of the territorial sea and the airspace super-adjacent to land territory, internal waters and the territorial sea. Referring to the subsoil, the rule universally accepted is that it belongs to the state which has sovereignty over the surface.

Territorial sovereignty can be defined as the general power of the state of government, administration and disposition known as 'imperium', a capacity recognized and delineated by international law. ${ }^{23}$

International practice is not uniform in regard to delimitation of the territorial sea, but international law does not permit an extension of the territorial sea beyond twelve miles.

The airspace superadjacent to land territory is in law a part of state territtory and as a consequence, other states may only use such airspace for navigation or other purposes with the agreement of the territorial sovereign.

The principle enunciated in the Convention of Paris of 1919 , that of sovereignty over the airspace above a state's territory, has been written into every agreement entered into by nations since that time. The Ibero-American Convention of 1926, and the Havana Convention of 1928, both laid out the sovereignty principle, as well as the Chicago Convention, of 1944, that states:

22. IAN BRownLIe - Principles of Public International Law, 1973, 2d ed. p. 280.

23. Ibid. p. 110 . 
art. 1: "the Contracting States recognize that every state has complete and exclusive sovereignty over the airspace above its territory."

The Chicago Convention does not, either in its body or in the annexes, define "air space" or "air", and it is a critical question to know where airspace ends. The only attempt to determine the boundaires between airspace and outer space is contained in the 53rd Conference of the International Law Association, held in Buenos Aires in August, 1968, which declared that:

"The term 'outer space' as used in the Treaty should be interpreted so as to include all space at and above the lowest 'perigee' achieved by 27 th January 1967, when the Treaty was opened for signature, by any satellite put into orbit, without prejudice to the question whether it may or may not later be determined to include any part of space below such perigee.'

4. General Principles of International Law relating to State Sovereignty.

a. The right of peoples and states freely to possess and dispose of their natural resources.

One of the essential attributes of state sovereignty on the one hand, and a necessary prerequisite of economic development on the other, is the right of peoples and states freely to possess and dispose of their natural wealth and resources.

In its tenth session, the General Assembly of the United Nations, and more speciafically its Third Committee, adopted the wording which was to become the second paragraph of art. 1 of the Covenant on Human Rights: ${ }^{24}$

24. In Djura Nincic - The Problem of Sovereignty in the Charter and in the Practice of the U.N. - 1970, pp. 265. 
"All peoples may, for their own ends, freely dispose of their natural wealth and resources without prejudice to any obligations arising out of international economic cooperation, based upon the principal of mutual benefit, and international law. In no case may a people be deprived of its own means of subsistence.

In January 1975, the Committee on Natural Resources adopted the Charter of Economic Rights and Duties of States, which affirmed that:

"Every state has and shall freely exercise full permanent sovereignty including possession, use and disposal over all its wealth, natural resources and economic activities." 25

b. The Principle of Non-Intervention in Internal Affairs.

The basic principle of international law is that of respect by each sovereign state for the territorial integrity and political independence of others. This principle was generally accepted in Europe after the devastations of the Thirty Years' War, and the axiom "Cuius Regio Eius Religio" had been accepted as the basis of the Peace of Westiphalia in 1648.

In spite of renewed efforts to put ideology ahead of territorial sovereignty at the time of the French Revolution and the Russian Revolution, this principle is still accepted in the U.N Charter, which is based on the "sovereign equality of all its members, requiring abstention from "the threat or use of force against the territorial integrity or political independence of any state" and prohibiting "intervention in matters which are essentially within the domestic jurisdiction of any State."

25. U.N. Doc. E/C $7 / 53-31$ Jan. $1975-$ Res $3281-\operatorname{XXIX.~}$ 
The Declaration on Inadmissibility of Intervention in Domestic Affairs of States and Protection of their Independence and Sovereignty ${ }^{26}$ reaffirming the principle of nonintervention in Internal Affairs estabishes:

1. No state has the right to intervene, directly or indirectly for any reason whatever, in the internal or external affairs of any other state. Consequently, armed intervention and other forms of interference or attempted threats against the personality of the state or against its political, economic and cultural elements, are condemned.

2. No state may use or encourage the use of economic, politic or any other type of measures to coerce another State in order to obtain from it the subordination of the exercise of its sovereign rights or to secure from it advantages of any kind. Also, no state shall organize, assist, foment, finance, incite or tolerate subversive, terrorist or armed activities directed towards the violent overthrow of the regime of another state, or interfere in civil strife in another state.

3. Every state has an inalienable right to choose its political, economic, social and cultural systems, without interference in any form by another state.

The Declaration on Principles of International Law Concerning Friendly Relations and Cooperation among States, adopted by General Assembly Resolution 2625 (xxv) . October 24, 1970 cover: non use of force, peaceful settlement of disputes, non-intervention by states in the domestic jurisdiction of other states, cooperation among states, equal rights

26. U.N. G.A. Res 2131 (XX) Dec. 21, 1965. 
and self-determination of peoples, sovereign equality and fulfillment in good faith of obligations assumed in accordance with the Charter.

The first Principle embodies art. 2(4) of the Charter:

"The Principle that states shall refrain in their international relations from the threat or use of force against the territorial integrity or political independence of any state, or any other manner inconsistent with the purposes of the United Nations."

The Special Committee could not resolve member differences to the definition of 'force' In qualifying statements, Argentina, the United Kingdom and the United States, thought force meant only physical or armed force. Nigeria, India and Venezuela asserted that force did, or should include economic or political coercion, despite the rejection by the Special Committee of proposed language to that effect.

The Declaration also established the Principle concerning the duty to intervene in matters within the domestic jurisdiction of any State in accordance with the Charter. For this purpose, intervention comprises economic, political or other types of coercion, including support or tolerance of subversive, terrorist or armed activities. This principle of nonintervention thus meets the objection voiced by several states to the ambiquity of the word 'force' in Principle I.

The Principle that states the duty of states to cooperate with one another in accordance with the Charter, is an embodiment of art. 1(3) of the Charter.

The Principle of equal rights and self determination of peoples declares that all peoples have the right to freely determine their political status and to freely pursue their economic, social and cultural development. 
By the analysis of the principle that establishes the right of peoples and states freely to possess and dispose of their natural resources and the principle of non-intervention in internal affairs it is clear that international law does not allow the detection of natural resources by remote sensing satellites, without the consent of the state sensed. The surveillance of military installations by satellites is also prohibited by the principle of non-intervention.

\section{The concept of espionage in international law.}

\section{Introduction.}

Since remote sensing activities involve a conflict between the regime of freedom in outer space and the principle of territorial sovereignty, special attention should be paid to the military uses of remote sensing activities, known as military reconaissance and also to the uses made of natural resources data acquired from remote sensing satellites, without the consent of the sensed state. Both activities can be classified as espionage from outer space.

Espionage has always played a prominent role in international relations. Five thousand years ago Egypt had a well organized secret service. King Thutmose III rescued the besieged city of Jaffa by smuggling into it two hundred soldiers sewn in fluor sacks. The greeks used the Trojan Horse to win their long war with Troy, and Joan of Arc was betrayed by a spy who was serving the English King. In the words of one observer:

"There never has been a war' without spies, and there never has been a peace in which spies have not engaged in preparations for a future war". ${ }^{27}$

27. in Wright, QUinct, Stone JULiUs, Falk A. Richard, S. Roland, Essays on Espionage and International Law, 1962. 
The phenomena of espionage, although often a significant force in international relations, never explicitly ascended to the state level of traditional international law. That is, the rules of the game allowed a state to employ spies and to prosecute foreign spies that it could catch. These two situations involved the relation between a government and an individual, whereas international law is concerned with the rules binding states in their relations with one another.

\section{Espionage in Conditions of Armed Conflict.}

The Hague Convention of 1907 did not make belligerent espionage a violation of the laws of war. For belligerent espionage is just one of several constituent forms of belligerency. According to its art. 29:

"An individual can only be considered a spy when acting clandestinely, or on false pretenses, he obtains, or endeavors to obtain information in the zone of operations of a belligerent with the intention of communicating it to the hostile party.

Thus, soldiers not wearing a disguise, who have penetrated into the zone of operations of a hostile army for the purpose of obtaining information, are not considered spies. Similarly, the following are not considered spies: soldiers and civilians, carrying out their mission openly, instrusted with the delivery of dispatches intended either for their own army or for the enemy's army. To this class belong likewise persons sent in balloons for the purpose of delivering dispatches and generally, of maintaining communications between the different parts of an army or a territory.

Art. 31 establishes that:

A spy taken in the act, shall not be punished without previous trial. A spy who, after rejoining 
the army to which he blongs, is subsequently captured by the enemy is treated as a prisoner of war, and incurs no responsibility for his previous acts of espionage"

Text writers generally recognize that while a spy, if captured in the act, can be executed after trial, his activities are not dishonorable, his government is not violating international law in sending him, and his act is not, therefore, a war crime.

The legitimacy of espionage in time of war arises from the absense of any general obligation of belligerents to respect the territory or government of the enemy state, and from the lack of any specific convention against it.

\section{Peacetime Espionage.}

In time of peace, however, espionage and in fact, any penetration of the territory of a state by agents of another state in violation of the local law, is also a violation of the rule of international law imposing a duty upon states to respect the territorial integrity and political independence of other states. There is no rule of international law which forbids a state to punish individuals who seek to obtain prohibited information, or fly over its territory without permission.

It is within the sovereign rights of each state to define peacetime espionage, sedition, subversion, sabotage, incitement and conspiracy as it sees fit, and it is the duty of other states to respect such exercise of domestic jurisdiction.

Among the cases of aerial espionage during peacetime, the U-2 incident (May, 1960) involving the overflight of Soviet territory by an American to obtain photographs of military targets deep in the Soviet Union, seems to be a good example. 
Following the shooting down of the spy aircraft, the U.S.A. sought to defend itself by asserting that such activity had taken place in an altitude beyond the sovereign of space and was necessary for self-defense. International law, however, permits military self-defense only in case of armed attack or at least immediate threat of armed attack. The danger apprehended by the United States flowed from an interpretation of Soviet policy and intent, not from an immediate threat or attack. But the reconnaissance activity is, however, an act of intervention, and cannot be justified on grounds of self-defense except in response to an actual attack or immediate threat of armed attack.

\section{Espionage Conducted from Outer Space.}

\section{a. Military.}

The perennial efforts of the United States to improve its knowledge of Soviet Military installations is well known. It has taken a variety of forms: the release of camera carrying ballons, the "open skies" proposal, U-2 overflights, reconnaissance observation by submarines operating within Soviet territorial waters, and more recently, reconnaissance satellites. The legality of these activities when conducted from outer space is defended on the ground of the extraterritorial character of the military reconnaissance satellites, and the territorial limits of national sovereignty.

But for the state that is the target of observation, it matters little where the unwanted observer locates himself. The functional quality of espionage from outer space is, from the viewpoint of information yield at least, no different from espionage in airspace. The present legal situation seems to be that although the United States is not forbidden to put military reconnaissance satellites in orbit, neither is the Soviet Union forbidden to shoot the satellites down. But, under present circumstances, it does not appear that a general 
rule justifying counter-intervention is expedient. Rather, action should be taken through the United Nations to terminate the original intervention. The rule of international law requering mutual respect by states for the territorial integrity and political independence of other states should be observed.

\section{b. Economic.}

The eventual utilization of earth resources data collected by one state through satellite observation of another state, without its prior consent, to the detriment of the state sensed, is not regulated by space law.

It is conceivable that if State A acquires through unauthorized observation from space, a more comprehensive or specific knowledge of the physical (including mineral) properties of state B, than State B itself possesses, such knowledge on the parte of state $A$ may represent a deprivation for state B. State A might as a result be placed in a more advantageous position than state $\mathrm{B}$ in any interaction where knowledge of the topography, geography, or geology of state B is significant. ${ }^{28}$ For example, advance knowledge of a certain agricultural disease in a crop which a state relied upon, could be used to that state's market detriment. So could advance knowledge of certain mineral deposits lead to the staking out of claims by foreigners in a manner prejudicial o the resource country. But this problem is not covered by space law.

Damage, as the term is used in Art. VII of the Space Treaty, seems to imply physical direct damage caused by the space object, and not indirect dagage which resulted from the intentional or negligent act of a party involving the use or dissemination of data. The same applies to Art. I of the Liability Convention.

28. See McDovgal, Lasswell and Vlasic, Law and Public order in Space (1963) p. 540. 
Although this matter is not regulated by Space Law, it is contrary to international law that states the principle of sovereignty of states over its natural resources which includes the information concerning such resources. ${ }^{29}$

It is also contrary to the principle that determines:

"No state may use or encourage the use of economic, politic or any other type of measures to coence another state in order to obtain from it the subordination of the exercise of its sovereign rights or to secure from it advantages of any kind." ${ }^{30}$

and also against the principle concerning

"the duty not to intervene in matters within the domestic jurisdiction of any state in accordance with the Charter." 31

Regardless of the place where the data is collected the use of it in detriment of the sensed state is an activity persecuted by national and international law. But at present there are no established sanctions due to the non-existence of specific regulations for remonte sensing activities.

29. "...his delegation endorsed the basic principle of consent, which was embodied in Article $\mathrm{V}$ of the draft submitted by Argentina and Brazil ... Without such consent, the resolutions reaffirming the principle of the permanent sovereignty of peoples and nations over their own natural resources would become to a large extent meaningless." Statement of the Chilean Delegate to the copuos Legal Subcommittee, 14th Session, Provisional Summary Record of the Two Hundred and Thirthy-Second Meeting, U.N. Doc. No. A/AC. 105/C.2/SR 232 at 4, (20 February 1975)); "All regulation of remote sensing should be based on respect for principle of the sovereignty of States, in particular over natural resources within their territories and over information relating to those resources." Statement of the Romanian Delegate to the COPUOS Legal Subcommittee, 14 th Session, Id., at 8.

30. see Declaration on Inadmissibility of Intervention in Damestic Affairs of States and Protection of their Independence and Sovereignty.

31. see Declaration on Principles of International Law concerning Friendly Relations and Cooperation among States. 
In the copuos, study in the "Legal Implications of Remote Sensing of the Earth by satellites" it was affirmed that:

"It is possible that a claim based on the private law concept of unjust enrichment might be attemted, if it could be proven that the operating state used the information to its economic advantage and that no benefit or compensation was received by the claimant state." $\mathbf{3 2}$

But this measure does not seem to be satisfactory as it will be very difficult for developing countries to prove economic espionage, as these countries at present do not have the means to verify which kind of activities are being carried on in outer space.

\section{Current regulations of remote sensing activities.}

1. Bilateral Agreements.

Although an international consensus has not been achieved in order to regulate remote sensing activities according to international law, bilateral agreements with the U.S.A. have been concluded since 1968.

The U S.A. has concluded bilateral agreements with Brazil (1968), Mexico (1968), Canada (1971), Italy (1974), Iran (1974) and Zaire (1974)

Several of these agreements have been amended or extended since the date of their conclusion. All but the one with Mexico provide for the establishment of LANDSAT earth receiving stations. All of these agreements provide for an open data policy. This open data policy means that all

32. U.N. Doc. A/AC 105/118 pp. 56, Copuos. 
LANDSAT date and pictures are considered to be in the public domain and that anyone may purchase copies.

Some forty countries have so far in one way or another participated in the LANDSAT program and many have purchased LANDSAT pictures. These participants are: ${ }^{33}$

a) Group of initial ERTS-I/LADSAT-I participants: Australia (577 ERTs), Brazil (general agreement), Canada (general agreement), Chile (372 ERTs), Colombia (305, 360 ERTs) Equador (371 ERTs), France (031, 051, 524 ERTS), Germány (Fed. Rep. - 328 erts/ERep), Greece (328 ERTS/EREP), Guatemala (369 ERTS), India (054 ERTS), Indonesia (004 ERTS), Korea ( 570 ERTs), Japan (021, 022 ERTs/FrEP), Mexico (general agreement), Norway (374. 375, 378 ERTs), Peru (302 ERTS), South Africa (577 ERTS), Switzerland (323 ERTS/EREP) U.K. (032, 033, 034 ERTs) and Venezuela $(117,120$ ERTS) .

b) List of countries or international organizations participating in the LANDSAT Follow-on investigations: Australia, Bolivia, Brazil, Finland, France, Gabon, Guinea, Iran, Italy, Japan, Kenya, Korea, Lybia, Malasya, Mali, Mexico, New Zeland, Norway, Pakistan, Peru, South Africa, Sweden, Switzerland, Thailand, Turkey, United Kingdom, Venezuela, South Vietnam, Zaire, Central Treaty Organization (regional investigations in Iran, Pakistan, Turkey), Fao Liptako-Gourma Authority (Earth Resources Inventory and Assessment of Upper Volta and Niger), ECAFE. 
Although bilateral agreements have been concluded with many countries, it is not an ideal solution. The power to choose which countries shall be permitted to use remote sensing facilities can result in a cold war politics.

The long-range inadequacy of bilateral agreements has been emphasized quite often, as for instance, at the 1971 copuos' Committee opening meeting:

"The increasing cooperation, especially between the major space powers, on a bilateral basis is a long-expected and most welcome development. I think, however, that this cannot and should not replace multilateral arrangements but should rather be aimed at complementing them. Multilateral cooperation in space is today undoubtedly the best and only possibility for all non-space powers, and in particular, for the developing countries to share the benefits from this new field of man's activity" 34

2. Current Draft Proposals before the United Nations Outer Space Committee.

In order to establish a multilateral agreement on Remote Sensing, Draft agreements on the subject have been presented to the United Nations Outer Space Committee ${ }^{35}$ by: Argentina ${ }^{36}$, Brazil ${ }^{37}$, France ${ }^{38}$, U.S.S.R ${ }^{39}$, France and U.S.S.R. ${ }^{40}$,

34. Speech by Kurt Waldheim, as Chairman of Copuos - U.N. Doc. A/AC 105/PV 98-106 p. 5 (Nov. 1971)

35. U.N. Doc. A/AC 105/133 of June 6, 1975.

36. Argentina: Draft International Agreement on Activies Carried out through Remote Sensing Satellite Surveys of Earth Resources (A/AC.105/C.s: L.73).

37. Brazil: Treaty on Remote Sensing of natural Resources by Satellites - Draft Basic Articles (A/AC.105/122)

38. France: Draft Principles Governing Remote sensing of the Earth Resources from Outer (A/AC.105/L69)

39. U.S.S.R.: Model Draft Principles Governing the Use of Space Technology by States for the Study of Earth Resources (A/AC.105/C2/L.88)

40. France and U.S.S.R.: Draft Principles Governing the Activities of States in the Field of Remote Sensing of Earth Resources by Means of Space Technology (A/AC.105/C.2/L.99) 
U.S.A. ${ }^{41}$, Argentina and Brazil seconded by Chile, Mexico. and Venezuela ${ }^{42}$. A comparison of the proposals made by these states leads to a subdivision of the seven most important items in the proposals as follows:
a) International Cooperation
b) Sovereignty
c) Responsability for Activities of Remote Sensing
d) Access to data
e) Authorization to use data
f) Consultation
g) Role of the United Nations.

a. International Cooperation.

All seven proposals emphasize that remote sensing activities have to promote internacional cooperation. The Brazilian proposal adds that 'the activities have to be carried out in accordance with the international law including the Charter of the U.N., the Treaty on Principles Governing the Activities of States in the Exploration and Use of Outer Space, including the Moon and Other Celesttial Bodies, and the principles contained in the Resolution of the United Nations General Assembly concerning Permanent Sovereignty of People and Nations over their Natural Resources, in particular resoluttions 1903 (xvII) of 14 December 1962, and 2158 (xxi) of 25 November 1966, art. 2)'

The French proposal stresses that remote sensing of the earth resources must be conducted "exclusively for peaceful purposes" (art. 1) The U.S.S.R. proposal insists that "space

41. U.S.A.: Legal implications of Remote Sensing of the Earth from Space; Working Paper on the Development of Additional Guidelines (A/AC. $105 / C .2 / L .103$ )

42. Argentina and Brazil seconded by Chile, Mexico and Venezuela: Treaty on Remote Sensing of Natural Resources by Means of Space Technology Draft Basic Articles (A/AC1/1047). 
technology must contribute to the independent economic development of all States.." (art. 3).

b. Sovereignty.

The most striking feature with regard to this subject is the fact that the U.S. working paper does not mention sovereignty at all. All other proposals contain specific references to national sovereignty and indepedence of states.

The Brazilian proposal includes, apart from sovereignty over a State's territory, also the resources located in maritime areas under national jurisdiction (art. 3) Moreover, the Brazilian proposal contains a disposal concerning prior consent on activities of remote sensing by another State in the one on whose territory natural resources are discovered (art. 4)

The joint Argentian/Brazilian proposal says in art. Iv: $\because$ "Not only the right to internal sovereignty and independence, but also the economic aspect of the freedom to use and distribute their wealth, whereby peoples may exercise their legitimate and exclusive sovereign rights over their own natural resources.

c. Responsibilities for activities of remote sensing.

The three proposals containing suggestions on this item are of: Argentina, Brazil, and the joint Argentian/Brazilian proposal.

Art. 4 of the Argentian proposal mentions 'expressis verbis' the prevention of the spoliation or destruction of the environment. Art. 11 of the Brazilian proposal says that States' parties shall be held internationally responsible for national activities, irrespective of whether such activities are carried out by governmental or non-govermental organizations. 
Art. XII of the Joint Argentian/Brazilian proposal gives in full length the same text as art. 11 from the Brazilian proposal.

d. Access to data.

The U.s.s.R. proposal is the only one that contains no suggestions in this respect.

Argentina proposes (art. 3 and 6) to establish a data bank, and France (in art. 6) adds the fair and reasonable terms for participation in such activities.

The U.s. Working Paper says that the United States wishes to make the remote sensing data available to (art. v): interested states, international organizations individuals, scientific communities and others, on equitable, timely and non- discriminatory basis. Art. v suggests that catalogues or other appropriate listings of available data be published on the data received from remote sensing satellites.

The joint Argentinian/Brazilian proposal contains in art. viII the following provision:

"States parties whose territory and maritime areas under their jurisdiction are the object of remote sensing of natural resources are entitled to full and unrestricted access to all data obtained through those activities.' (art. $\mathrm{x}$ )

e. Authorization to use data.

The joint Argentina/Brazilian proposal in Art. X states that: "States parties shall refrain from soliticing, accepting or, in any manner, receiving from a third state, international organization or private entity, information regarding the natural resources of another State Party obtained through remote sensing without the express authorization of the State 
Party to which the natural resources belong, nor can they utilize such information to the detriment of the latter."

The French proposal states (art. 5.2) that use of the documents resulting from a remote sensing operation may not be granted to third parties, without the consent of the State whose territory is affected.

\section{f. Consultation.}

The joint Argentian/Brazilian proposal suggests in Art. xIv that "Disputes resulting from activities of remote sensing of natural resources shall be resolved in accordance with the methods envisaged in art. 33 of the Charter of the United Nations.

\section{g. Role of the United Nations.}

The Argentian Draft requests (under art. 2, not repeated in the joint Argentian/Brazilian Draft Proposal) for the responsibility of the United Nations Secretariat for the functions of planning, consultations, information etc, until some other appropriate body is available to take care of this task.

The French proposal is (art. 4) in slightly different wording also contained in the joint French/Soviet Proposal that says: "to inform the Secretary General of the United Nations of the date, duration, nature and obejtives of the remote sensing activities of the States Partties as well as of the areas which may be affected by remote sensing activities.

A proposal, similiar to the French one, was made in the USA Working Paper, where art. II stresses that "satellites. for remote sensing. . be registered with the SecretaryGeneral of the U.N., in accordance with the Convention on Registration of Objects Launched into Outer Space. 
The presentation of the Draft Treaties by these nations gives a picture of the divergent political interests of the superpowers and the developing nations.

Although the U.S.A. does not mention sovereignty in its proposal, developing countries such as Argentina and Brazil stress its importance. The U.S.S.R. does not refer to the access of data, an important problem that is regulated in the joint Argentian/Brazilian proposal.

The two super-powers are the only nations which have the tools to explore outer space and obtain data from the earth, yet they do not seem to be eager to share their position with the underprivileged nations.

An effort should be made in the United Nations to bring about a cooperative relationship based on inter-dependence, that is, on the maintenance of the sovereign rights of all parties, and not on dependence, which implies a loss of sovereignty.

\section{Conclusions and recomendations.}

1. Conclusions.

a. In the present situation, when remote sensing activities are performed without conclusion of a bilateral agreement, the principle of territorial sovereignty as defined in national and international law is not observed. Therefore, remote sensing activities can be regarded as espionage, under national and international law.

b. Since bilateral agreements are not a satisfactory measure, as they can result in cold war politics, a multilateral agreement must be adopted. This agreement shall establish the prior consent of the sensed state and the authorization for dissemin- 
ation of data as fundamental conditions for remote sensing activities.

\section{Recommendations.}

It is recommended that a new international organization be created, which would be empowered to negotiate with any state contemplating the launching of a remote sensing satellite. The United States and the U.S.S.R. would retain the basic decision-making power. Once that decision is made, within carefully limited boundaries, the member countries would be free to decide on which among them would be given priorites and what types of experiments could be conducted.

A Technical Commission should be created within the new international organization which would be able to make highly technical decisions concerning the nature of the experiments to be permitted and political decisions concerning the scheduling of experiment by the member countries. ${ }^{43}$

This body should be modeled on the International Frequency Registration Board of the International Telecommunication Union which was designed to merge extremely high technical skills and at the same time provide a basis for third party decision making.

As the United Nations has defined several programs to develop poor countries ${ }^{44}$, there should be no payment for services, but a nominal fee may be required.

A basic document of this new international organization should be based on several sources. The first is the Treaty

43. see Codding JR. and BeHeshti - An International Agency for Earth Resources Experiments - in Journal of Space Law - v. I 1973 p. 40.

44. Developed countries and developing countries should further cooperate through investment of financial resources and supply of technology and equipment to developing countries. (UNGA Res 3362 - Sept. 16, 1975 - Development and International Economic Cooperation, sec. II, item 10) . 
of the International Telecommunication Convention ${ }^{45}$, which can provide a model for a Technical Commission. The second should be the basic document of Intelsat ${ }^{46}$, which deals with space activities. It can also be based on many regulations of the U.N Informal Single Negottiatitng Text for the establishment of the International Sea-bed Authority. ${ }^{47}$

However, it is predicted that the conclusion of a Treaty on Remote Sensing and the implementation of this recommendation by the United Nations will not be reached in the near future. In spite of the concern of developing countries about the serious threat to the security of the world through the non-observation of the principle of territorial sovereignty, the subject of remote sensing activities does not have a high priority on the U.N copuos agenda.

\section{Bibliography}

Books

ARON, RAYMond. Peace and War: a Theory of International Relations. (New York: Praeger, 1970)

Blix, Hans. Sovereignty, Agression and Neutrality. (The Dag Hammarskjold Fundation, 1970)

Brownlie, JAN. International Law and the Use of Force by States (Oxford, 1963)

45. International Telecomunication Convention - General Secretariat of the International Telecomunication Union, Geneva, 1965.

46. Intelsat - International Telecomunications Satellite Organization was established on 12 February 1973, as a result of the entry into force on that date of two international agreements: the 'Agreement relating to the International Telecommunications Satellite Organization 'intelsat' concluded among governments, and the "Operating Agreement, relating to the International Telecomunications Satellite Organization, Intelsat, concluded among governments of their designated telecomunications entities.

47. Draft U.N. Convention on the International Seabed Area, working paper $\Lambda$ ugust 3,1970 and Informal Single negotiating Text - A/Conf. 62 W.P. 3/Part 7 May 1975. 
Brownlie, JAN. Basic Documents in International Law. (Oxford: Clarendon Press, 1967)

Brownlie, JAN, Principles of Public International Law, 2d edition. (Oxford: Clarendon Press, 1973)

COOPER, JоHN CовB. Exploration in Aerospace Law - Selected essays edited by Ivan A. Vlasic. (Montreal: McGill University Press, 1968)

DoN, E. KASH. The Politics of Space Cooperation. (Pardue Research Foundation, 1967)

Gal, Gyula. Space Law. (New York: Oceana, 1968

De VIsscher, Charles. Théories et Réalités en Droit International Public. 4ème édition. (Paris: Editions A. Pedone, 1970)

LARSON, A., JENKS, WILFRED C. and others. Sovereignty within the Law. (New York: Oceana, 1965)

LAY, S. HOUSTON and TAUBENFELd, H.J. The Law Relating to Activities of Man in Space. Chicago: University of Chicago Press, 1970).

McDougal, Lasswell and Vlasic. Law and Public Order in space. (New Haven: Yale University Press, 1963)

NinciT, DJurA. The Problem of Sovereignty in the Charter and in the Practice of the United Nations. (The Hague, 1970)

VERWEY, W.D. Economic Development Peace and International Law. (1972)

VINCENTON, R.J. Non Intervention and International order (Princeton, New Jersey, 1974)

VIASIC, I.A. The Relevance of International Law to Emerging Trenas in the Law of Outer Space in Falk \& Black, eds. The Future International Legal Order, vol. II, Chapter 4.

Wright, Quincy, Stone, Julius, Falk, A. Richard, Stranger, J. Roland. Essays on Espionage and International Law. (Ohio State University Press, 1962)

\section{Articles and Papers.}

Adams, R. Thomas. The Outer Space Treaty an Interpretation in Light of the non Sovereignty Provision. Harvard International Law Journal (vol. 9 , p. 1, Winter 1968).

Bourely, M. Europe and Remote Sensing. A paper presented on the Symposium on Legal Implication of Remote Sensing from Outer Space. Institute of Air and Space Law, McGill University, Montreal, October 16, 1975 .

Codping, J.G. and Befesht, M. An International Agency for Earth Resources Experiments Journal of Space Law (v. 11, 1973). 
Colwell, Robert N. Peaceful Uses of Photo Reconnaissance Satellites in Open Space and Peace - A symposium on effects of Observation, ed. by F.J. Ossembeck, the Hoover Institution, Stanford University, California, 1964.

Dalfen, Charles M. The International Legislative Process: Direct Broadcasting and Remote Earth Sensing by Satellite Compared, in The Canadian Yearbook of International Law, 1972.

Dekanozov, R.V. Relationship between the Status of Outer space and the Statutes of areas withdraw from State Sovereignty in Proceedings of the XVIth Colloquium on the Law of Outer Space, International Institute of Space Law of the International Astronautical Federation. October 7, 1973.

Fedele, Frank. Peacetime Reconnaissance from Air Space and Outer Space: A study of Defensive rights in Contemporary International Law" Thesis presented at Institute of Air and Space Law, McGill University April, 1965.

Galloway, Etlene. Remote Sensing from Outer space: Legal Implication of Worldwide Utilization and Dissemination of Data. Paper presented on the Symposium on Legal Implications of Remote Sensing from Outer Space. Institute of Air and Space Law, McGill University, Montreal, Canada, October 16, 1975.

GaEdhius, D. The Presented State of Space Law. The Netherlands, 1973. International Law Association Editor Prof. Dr. Maarten Bas.

Gorove, Stephen. Earth Resources Survey Satellites and the Outer Space Treaty. Journal of Space Law, v. 1, 1973.

Hervy, Le Concept Juridique de Souverainété et le Droit Spatial, XXVI Congrès International d'Astronautique Lisbonne, Septembre 1975.

HitT, R. William. A Treaty on Remote Sensing Activities. A thesis submitted to the Faculty of Graduate Studies and Research in partial fulfilment of the requirements for the Degree of Master of Law. Institute of Air and Space Law, McGill University, Montreal, August, 1975.

KhaN, MUMTaz Almed. Arms control, Disarmament and Observation in Space: Recent Developments. A thesis submitted to the Faculty of Graduate Studies and Research in partial fulfilment of the requirements for the Degree of Master of Laws. April, 1968.

LUstgarten, LIONEL. Legal and Organizational Aspects of Remote Sensing of Earth Resources from Outer Space. A thesis submitted to the faculty of Graduate Studies and Research in partial fulfilment of the requirements for the degree of Master of Law. July, 1972.

MaNkIEwICZ, RENÉ. Interpretation of the Treaty of Outer Space. In Proceedings of the llth Colloquium on the Law of Outer Space. International Institute of Space Law of the Institute of Astronautical Federation 1969 .

Markov, M.G. Implementing the Contractual Obligation of Art. I \& 1 of the Outer Space Treaty, 1967" in "Il Diritto Aerco". Rivista di Dottrina, Jiurisprudenza e Legislazione. 50, II Trim 74. 
RaIJnen, G.C.M. Remote Sensing by Satellites and Legality. The Astronomlcal Institute at Utrecht. The Netherlands.

Robinson, George S. World Wide Utilization and dissemination of data Acquired through Remote sensing. A paper presented on the Symposium on Legal Implications of Remote Sensing from Outer Space. McGill University, Montreal, October 1975.

RobINSON, Marvin, Remote Sensing from Outer Space: Role of the United Nations, paper presented on the Symposium on Legal Implications of Remote Sensing from Outer Space. Institute of Air and Space Law, McGill University, Montreal, October 16, 1975.

StOEBNER, A.W. Télédétection des resources terrestres technique et droit a paper presented on the Symposium on Legal Implication of Remote Sensing from Outer Space. Institute of Air and Space Law, McGill University, Montreal, October 16, 1975.

Trafford, Diana. Eye in the Sky In Search - the Canadian Communications Quarterly, Fall/automne, 1975.

Vuasic, I.A. Space Lawyers, New Technology and the Question of Priorities" Reprinted from Organizing Space Activities for World Needs. Edited by E.A. Steineroff Pergamon Press, Oxford \& New York, 1971.

Wrulams, S.M. Earth Surveying from space in the Light of the Principle of Sovereignty. Proceedings of the 16th Colloquium on the Law of Outer Space - International Astronautical Federation. October 7 13, 1973 . 